\title{
Patterns of Care (Parenting) Children with Special Needs
}

\section{Gede Wira Bayu' ${ }^{*}$, Nyoman Kusmariyatni²}

1,2 Universitas Pendidikan Ganesha

\section{A R T I C L E I N F O}

Article history:

Received 01 December 2018

Received in revised form

31 December 2019

Accepted 15 January 2018

Available online 25

February 2019

Keywords:

Patterns, parenting, children with special needs, parents, teachers

\section{A B S T R A C T}

The purpose of this study was to investigate the patterns of care of children with special needs in Sjakitarius Foundation Singaraja. The research employed a case study design, including 30 children with special needs, their parents, and teachers. The data were obtained through observation, interview, and document recording. Then the data were processed by using a snow ball technique. The study reveals three themes. Firstly, children with special needs had a tendency to have social interaction deficits (narrow, very limited) with a $74 \%$ presentation. They also experienced as many as $85 \%$ verbal and nonverbal communication disorders with repeat stereotype, and restricted (95\%) stereotype or interest, as well as behavior (100\%), which occurs before the age of three. Secondly, the appropriate parenting pattern applied by parents to children with special needs is begun with (1) becoming a parent who deserves to imitate children, (2) not educating children at a cost that cannot be banned by their parents, (3) discipline still must be prioritized in guiding children, (4) putting forward and cultivating early on religion and good moral in children, (5) communication is done openly and fun with certain limitations, (6) avoiding negative actions toward children. Lastly, the appropriate parenting patterns applied by teachers to children with special needs are initiated by (1) becoming a creative and innovative teacher, (2) having unlimited patience, (3) being a positive model, (4) communicating openly like a parent, (5) avoiding negative behaviours. 


\section{Introduction}

Educating children properly and correctly means nurturing the potential totality of children naturally. The physical potential of the child is strived to grow naturally through the fulfilment of physical needs, such as the fulfilment of clothing, food and shelter needs. While the spiritual potential of the child is strived to develop its development through intellectual coaching, feeling and character.

Children are born in the care of parents and raised in the family. Parents serve as caregivers, mentors, carers and as educators of their children. Every parent would want their children to be intelligent and morally humans. However, many parents do not realize that the way they educate makes children feel unnoticed, limited freedom, and some even feel unloved by their parents. Feelings that affect a lot of attitudes, feelings, ways of thinking and even their intelligence.

In addition to parents in the family, schools also play a very vital role in early child development and growth in the category of children with special needs. Schools are considered their place to mingle and understand many things that have not been in the care of the family environment.

Of course the school provides good treatment for children with special needs, schools prepare themselves with all means-pre facilities and qualified educational personnel in accordance to support the success of parenting children with special needs that parents apply to the conditions at school. Based on the above conditions, the appropriate parenting pattern is needed so that children of early age, especially those with special needs can develop well and independently.

Patterns of Care (Parenting Rules)

The pattern of care that is usually applied to the family environment is as follows:

1. Authoritarian Parenting Patterns

According to Stewart and Koch cited in Aisha (2010), parents who apply authoritarian parenting have characteristics such as: stiff, firm, punitive, lack of affection and sympathetic. Parents force children to be obedient to their values, and try to shape the behavioral circles according to their behaviour and tend to curb the wishes of the child.

\section{Democratic Care Patterns}

Baumrind \& Black from his research found that democratic parental care techniques that foster confidence and self-confidence and encourage independent actions make their own decisions will result in the emergence of responsible, independent behaviours.

Stewart and Koch state that democratic parents view equal duties and rights between parents and children. Gradually, parents give their children responsibility for everything they do until they grow up. They always have dialogue with their children, give each other and receive, always listen to the complaints and opinions of their children. In acting, they always give the reason to the child, encourage the children to help each other and act objectively, firmly but warmly and understandingly.

\section{Permissive Care Patterns}

The type of parent who has a permissive parenting tend to always give freedom to the child without giving any control at all. Children are very little required for a responsibility, but have the same rights as adults. The child is given the freedom to self-regulate and the parents do not manage much of their children.

According to Spock in Aisha (2010), permissive parents give their children to do what they wish and are very weak in carrying out discipline in children. Hurlock in Aisha (2010) states that the pattern of permissive care is characterized by inadequate control, the parents are being loose or free, less guidance to the child.

\section{Pattern of Parent Treatment}

Parents with all their desires for children to develop well, usually have the following attitudes: (1). Overprotection (overprotective), (2). Pattern of Parental Behaviour: Permissiveness (acquisition), (3). Parental Behaviour Pattern: Rejection (Rejection), (4). Parental Behaviour Pattern: Acceptance (acceptance), (5). Pattern of Parental Behaviour: Domination (domination), (6). Parenting Behaviour Patterns: Submission (submission), (7). Pattern of Parental Behaviour: Punitiveness/Over discipline (too disciplined).

In accordance to children with special needs parents are required to be more patient and are able to choose which treatment is roughly appropriate for children adjusted to the conditions that occur in the child. 
The Role of the Family in Child Care

Some of the roles of families in child care are, as follows:

The establishment of harmonious relationships within the family through the application of good parenting patterns early on, namely: a) Child care and care begins from pre-conception of marriage, b) Parenting and child care in the womb, after birth and until adulthood and beyond are provided with full affection and guidance of religious children, c) Providing the best education for children, especially religious education, d) Patience and sincerity. The patient's patience and sincerity can lead to the success of the child, e) Can build good relationships between individuals and have the spirit of brotherhood, f) Parents are obliged to seek happiness for the child and accept the child's situation for what it is, appreciate the blessings given by God, and develop the potential of the child.

Basic Concepts of Children with Special Needs

Two differences to understand children with special needs: the interindividual and intraindividual.

1. Interindividual Differences

Comparing the state of the individual with others in various ways such as differences in mental state (capacity of intellectual ability), sensory ability, motor ability, communication ability, social behavior, and physical condition. The recent development of differences in students' achievement in various subjects.

2. Intraindividual Differences

Is a comparison between the potential that exists within the individual; these differences can arise from various aspects including intellectual, physic, psychology, and social.

Types of Children with Special Needs

1. Mental abnormalities consist of:

a. Mental High

Often known for intellectually gifted children, where in addition to having an intellectual ability above a normal average that also has significant creativity and responsibility to the task.

b. Mentally low

Low mental ability or intellectual capacity (IQ) below the average can be divided into 2 groups of slow learners i.e. children who have an IQ between 70-90. While children who have an IQ below 70 is known for children with special needs.

c. Specific Learning Difficulties

Learning difficulties related to the achievement of learning (achievement) obtained by students. Children with specific learning disabilities are children who have normal intellectual capacity up but have low learning achievement in certain academic field.

2. Physical abnormalities include:
a. Body Abnormality (Tunadaksa)
b. Sensory Impairment Vision (Blind)
c. Audience Index Hearing (Deaf)
d. Speech disorders

\section{Emotional Disorders}

Emotional disturbance is a psychological problem, and can only be seen from indications of behavior that appear in the individual, as for the classification of emotional disorders includes: a) Behavioural Disorder, b) Concentration Disorder (ADD/Attention Deficit Disorder), c) Hyperactive Children (ADHD/Attention Deficit with Hyperactivity Disorder)

Thinking Framework

Children with special needs of course must also be given special treatment so that they are able to develop themselves in accordance with the stages of development by improving the attitude and behaviour in order to be independent.

To support this, parents at home and teachers in school demanded to have the appropriate parenting for children with special needs in line with the characteristics that they have (see the chart below): 


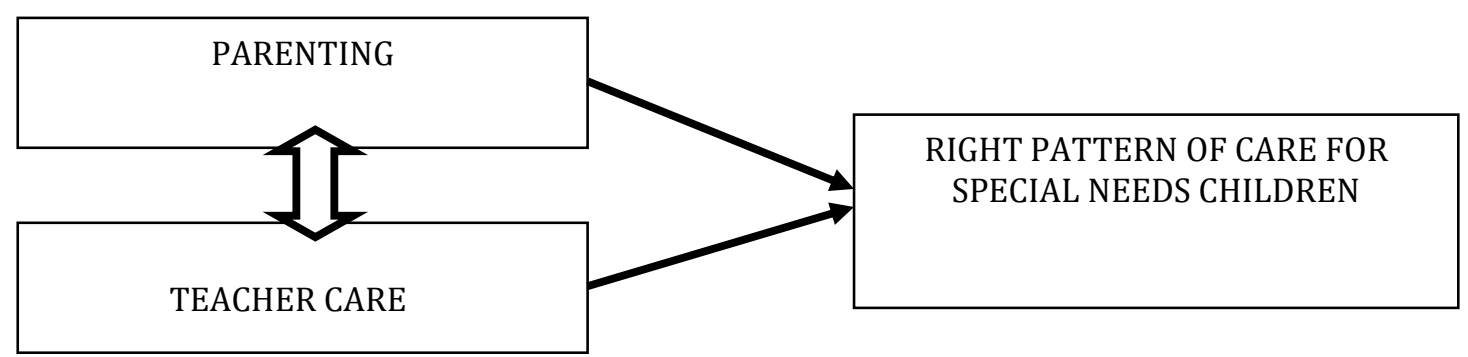

Chart 1: Thinking framework

\section{Methods}

\section{Research Approach}

This research employed qualitative approach that is responsive and creative in accordance with the form of rhythm and possibilities that exist in the field through the observation of actively involved with trying to prolong existence in the community. The data collection techniques were in-depth interviews with a number of informants consisting of teachers and parents of children with special needs selected by using the snowball effect technique with triangulation principle (Miles and Huberman, 1992) and observation. The strategy for achieving research objectives is by case study method (Yin, 1996). The type of data in this study consists of primary data and secondary data.

\section{Location and Subject of Research}

This research was conducted at Sjakitarius Foundation Singaraja School for 8 months starting from April until October. The Sjakitarius Foundation is located at Jalan Toya Anakan 2, LC 8 No. 27 Baktiseraga, Singaraja. All children with special needs who registered in the school, their parents, and the teacher were involved as subjects in this study.

\section{Data Collection Method}

The data were collected by using several research instruments, namely: a. observation guide sheet, b. interview guidelines, c. field notes, and d. document recording.

\section{Processing Techniques and Data Analysis}

Primary data were obtained from interview with informant. In one session, 10-20 children with special needs, 5-8 teachers, and 20-30 parents were interviewed, so that all informants in this study approximately amounted to approximately 45 people for minimal three months. As for the secondary data, they were obtained from related institutions, research reports, literature, and scientific papers.

The data that have been obtained contained holistic perspective with the whole individual approach through the extraction of "texts" of the interview result with the purpose of constructing a descriptive abstraction of the casuistic social reality with the data reduction step, data presentation and drawing conclusion

\section{Result And Discussion}

\section{Research result}

In conducting research at Sjakitarius Foundation Singaraja, researchers found several obstacles, such as: (1) lack of parents' willingness to have their children observed in their behaviour, (2) lack of parents' willingness to be interviewed about their children. But it does not dampen the intention of researchers to continue this research until finally the researchers were able to observe the complete behavior of most children with special needs who actively followed the learning in this Sjakitarius Foundation. Based on the observations, interviews, and document recording, the results show: ASD/PDD: Main Symptoms

Children with special needs experienced a social interaction deficit (narrow, very limited) with a percentage of $74 \%$. They also xperienced verbal and non verbal communication disorders as many as $85 \%$; with repetitive (stereotyped) and restricted behavior (95\%) as well as the behavior that occurs before the age of three years $(100 \%)$. 
Communication Style of Parents in Children

$60 \%$ of parents tend to or often use the word "Must", "must", "Should not", "Do not" when they communicated with their children in situations, such as when their children ate or bathed. $80 \%$ of people tend to or often use the phrase "Yes deh ... yes ... mom/mama ngalah ... take all your sister/you '," may "," up brother/you just ... mom/mama is dizzy "or other similar words when they interacted with the children. This happened in a context when a 'stubborn' kid did not listen to instruction or when the child was fussy. $80 \%$ of parents tend not to use sentences that give children a choice like "According to sister, which one is better?", "Please brother/you think well, so do not regret later", 'What's the difference of yesterday's swimming pool with the Swimming pool now? "'According to which brother/sister is more exciting which one? "Or other similar sentences when they talked to their kids.

\section{Discussion of Research Results}

Based on the results of research conducted at the Sjakitarius Foundation Singaraja, it was found out that children with special needs have a tendency to experience social interaction deficits (narrow, very limited) with a percentage of $74 \%$. Then experience verbal and nonverbal communication disorders as much as $85 \%$. With repetitive (stereotyped) and restricted behaviors (95\%), and the behavior that occurs before the age of three is $100 \%$.

Children with special needs have behaviors that are different from most normal children. Their response to the environment is not unusual (strange, is limited, do not connect), like doing the same thing, behaviours/movements over and over again (stereotypes), although some of them show special interests such as being able to play a musical instrument in the form of organ well and are able to play laptop well too.

Some children have a dependence/attached to a particular object (unusual) as HP inseparable except when they went to school or to the bathroom. Others have self-injury behaviors when they were asked to do unwanted things (forbidden to interfere with people who are working) or when they were angry. But there were children who have the ability to draw the "extraordinary" (very detailed, sharp/object-like perspective.

At the age of two children with special needs usually can provide a response to the general events and tried to reach his parents from a distance and can understand the words other than routine spoken word even though children do not expect. While at the age of three the child begins to show his/her fingers to tell something, and do strange things. The child has also begun to use the hands of his parents as a 'tool' to show his desires. At this age also children can say words that are meaningful in repetitive and spontaneous.

In the process of communicating between the child and the parent usually the parents will be firm to the child because the child tends to be stubborn and cannot show obedience. Sometimes parents succumb to the child when the child cannot be directed and sometimes even hurt his parents by pinching. Parents rarely give choices to children because children do not understand.

Parents know their children with special needs when they are over 1.5 years old. They immediately consulted the doctor and found a special school for them. Parents are also trying to create a comfortable environment for the sake of their children.

Based on the above description there are several ways/patterns of care to educate children with special needs that can be applied as a parent:

Both mom and dad should agree to choose the apporpriate parenting that will be applied to the child. Do not be wise and fickle so the child does not get confused.

Be an exemplary parent by modelling positive things in everyday life. Do not let the child be forced to do good things that his parents do not want to do. Children will respect and appreciate their parents so that adults will love the parents and other family members.

Adjust the pattern of care with the situation, conditions, abilities and needs of children. Poultry foster children under five would be different from the pattern of foster teenagers. Do not educate children at a cost that their parents cannot afford. Keep the child easy to understand with what we want without feeling any coercion, but on the basis of self-awareness.

Discipline should still take precedence in guiding children from early to adulthood so that children can be independent and respected. Small things like getting up on time, helping with parenting, studying diligently, are one form of discipline and responsibility for children.

Emphasize and cultivate early on religion and good morality in the child so that the future can be a virtuous person and have good and religious attitude and behaviour. A pious child will always pray for the parents who have given birth and raised her even though her parents have passed away.

Communication is done openly and fun with certain limitations so that children are used to open to parents when there is something to be conveyed or things that interfere with his mind. If angry parents 
should use a good and indirect expression that can be understood by children so that they do not necessarily become closed and consider parents unpleasant.

Avoid negative actions in children such as scolding children for no reason, sending children as casually as unlimited helpers, dropping children mentally, smoking, lazy worship, fooling children, lying to children often, bringing home stress from the office, feeding money from illicit children, reluctant to take care of children, too busy with work and so forth.

While the ways/patterns of care that can be done by teachers in schools in children with special needs are as follows:

Be a creative and innovative teacher figure to be able to provide a fun learning process and not boring. Children with special needs usually will very quickly get bored and less able to socialize well. This is where the role of creative and innovative teachers is needed.

Have unlimited patience. As a normal human teacher must have limitations. But in dealing with children with special needs teachers are expected to be more aware than usual. Children with special needs most difficult to direct and given orders.

Be a positive model. Early childhood will usually mimic the stereotype that surrounds it. As a figure most often encountered by children after parents, teachers should be able to model the introduction of positive values that exist in society.

Communicate open like a parent. Early childhood is very difficult to communicate well. For that, teachers should be able to make a communication style similar to parents at home so that children can express their desires well.

Avoid negative behaviour. Like parents at home, teachers are also asked not to behave negatively in front of children with special needs. For example, if the teacher is already 'smoking' then do not smoke in front of children.

\section{Conclussion} follows.

Based on the results of research and data analysis conducted, it can be concluded several things as

a. Lack of parental awareness of proper parenting patterns in early childhood.

b. Children with special needs experience a social interaction deficit (narrow, very limited) with a percentage of $74 \%$. Then experience verbal and non verbal communication disorders as much as $85 \%$. With repetitive (stereotyped) and restricted behaviour (95\%), and the behaviour that happens before the age of three $(100 \%)$.

c. Appropriate parenting pattern applied by parents to children with special needs is initiated by: 1) being a parent who deserves to imitate children; 2) do not educate children at a cost that their parents can not afford; 3) discipline should always take precedence in guiding the child; 4) Emphasize and cultivate early on religion and good morals in children; 5) communication is done openly and pleasantly with certain limitations; And 6) avoid negative actions in children.

d. Appropriate parenting pattern applied to teachers in children with special needs is preceded by; 1) being a creative and innovative teacher figure; 2) have unlimited patience; 3) be a positive model; 4) communicate openly like a parent; And 5) avoid negative behaviour.

e. Lack of government participation in the education of children with special needs because in the research revealed that the Sjakitarius Foundation was founded by Dutch citizens named Thijs van Harta, while for the local area of Buleleng there is no similar school owned by the government.

\section{Reference}

Alimul, H. 2007. Research Methods and Data Analysis. Jakarta: Salemba Medika

Daryati, R. 2009. Establish a good self image through Pattern of Child Care in Raising.

Dewi, I. 2008.Mengenal Parenting Shape Pattern Parent

Godam. 2008. Type/ Type Kind of Pol Aasuh Parents In Children And How To Educate / Raise Good Children. From Http: www.Organisasi.org community and library online.Diakses taanggal March 22, 2016.

Kartono, Kartini. 1992. The Role of Family Guiding Kids, Jakarta 
Miles, B. M. \& Huberman, A. M. 1992. Qualitative Data Analysis. University of Indonesia Press. Jakarta. Patmonodewo, S. 2003. Pre-School Child Education. Jakarta: PT Rineka Syamsu, J. 2009.Psikologi Child and Adolescent Development.

Yin, Rober K. 1996. Case Study: Design and Method. Rajawali Pers. Jakarta 